\title{
Antena Patch Array untuk Portable Coastal Radar pada Frekuensi $S$-Band
}

\section{Array Patch Antenna in S-Band Operational Frequency for Portable Coastal Radar}

\author{
Folin Oktafiani * dan Yussi Perdana Saputera
}

Pusat Penelitian Elektronika dan Telekomunikasi, Lembaga Ilmu Pengetahuan Indonesia. Komplek LIPI Gd 20, Jl Sangkuriang 21/54D, Bandung 40135, Indonesia

\begin{abstract}
Abstrak
Penelitian ini bertujuan untuk mendesain antena Portabel Coastal Radar yang bekerja pada frekuensi S-band dengan frekuensi tengah $3 \mathrm{GHz}$. Jenis antena yang digunakan adalah antena patch mikrostrip. Satu modul antena terdiri dari 4 patch yang di-array secara horisontal dan dicatu dengan menggunakan konektor SMA. Bahan yang digunakan untuk mendesain antena adalah FR4 dengan ketebalan substrat 3,2 mm serta memiliki nilai $\varepsilon_{\mathrm{r}}=4,3$. Bandwidth yang diperoleh dari hasil simulasi satu modul antena sebesar 80,1 MHz untuk nilai VSWR $\leq 1,5$ di mana sudah memenuhi spesifikasi antena yang diinginkan. Hasil simulasi beamwidth horisontal dan gain satu modul antena secara berturut-turut yaitu $37^{\circ}$ dan $8,049 \mathrm{~dB}$. Untuk mendapatkan beamwidth horisontal $<1^{\circ}$ maka satu modul antena di-array secara horisontal sebanyak 30 buah sehingga panjang keseluruhan antena menjadi $3600 \mathrm{~mm}$. Beamwidth horisontal antena array hasil simulasi diperoleh sebesar $0,9^{\circ}$ sedangkan gain antena meningkat menjadi $21,11 \mathrm{~dB}$.
\end{abstract}

Kata kunci: antena, mikrostrip, array, radar.

\section{Abstrack}

The aim of this research is to design portable coastal radar antenna that works on S-band frequency with a center frequency $3 \mathrm{GHz}$. The type of antenna used in this research is microstrip patch antenna. One antenna module consists of four patches which are horizontally arranged and fed with SMA connector. The used material for antenna design is FR4 with a substrate thickness of $3.2 \mathrm{~mm}$ and has $\varepsilon_{r}$ value of 4.3. Bandwidth obtained from the simulation results of one antenna module for VSWR $\leq$ 1.5 is $80.1 \mathrm{MHz}$ where it meets the desired specifications of the antenna. Simulation result of horizontal beamwidth and gain of one antenna module is $37^{\circ}$ and $8.049 \mathrm{~dB}$, respectively. To obtain horizontal beamwidth $<1^{\circ}$ then 30 antenna modules are arranged in a horizontal direction so that the overall length of the antenna is $3600 \mathrm{~mm}$. From simulation results the horizontal beamwidth of array antenna is obtained by $0.9^{\circ}$ while the antenna gain is increased to $21.11 \mathrm{~dB}$.

Keywords: antenna, microstrip, array, radar.

\section{Pendahuluan}

Negara Kesatuan Republik Indonesia (NKRI) adalah salah satu negara terbesar di dunia. Untuk kawasan ASEAN, wilayah NKRI adalah yang paling luas. Pengamanan dan pengawasan wilayah NKRI yang terdiri dari kurang lebih 17.504 pulau dengan 2/3 wilayah terdiri dari lautan memerlukan aparat dan peralatan yang berjumlah besar. Kemampuan TNI dan Polri untuk mengawasi wilayah RI sangat terbatas sehingga wilayah perairan Indonesia rawan akan pencurian ikan, pelanggaran wilayah oleh kapal-kapal asing, pembajakan kapal laut dan penyelundupan. Wilayah udara Indonesia (terutama di Indonesia timur) juga rawan akan penyusupan oleh pesawat udara asing [1].

Khusus untuk wilayah perairan, salah satu cara untuk meningkatkan kemampuan aparat pemerintah

\footnotetext{
* Corresponding Author.

Email: folin@ppet.lipi.go.id

Received: May 31, 2013; Revised: June 18, 2013

Accepted: June 27, 2013

Published: June 30, 2013

(C) 2013 PPET - LIPI

doi : $10.14203 /$ jet.v13.18-22
}

dalam mengawasi dan mengamankan wilayah NKRI adalah dengan menggunakan radar coastal. Radar ini digunakan untuk mengawasi pergerakan kapal-kapal laut sehingga dapat dicegah tindakan-tindakan yang dapat merugikan NKRI dan juga tabrakan kapal apabila hendak merapat ke pelabuhan.

Kebutuhan radar di Indonesia mulai dari 800 hingga 900 buah, tetapi jumlah yang terpasang saat ini masih di bawah angka 30 dan semuanya buatan asing. Di antaranya adalah delapan radar buatan AS yang dipasang di sepanjang Selat Malaka [2].

Karena fungsi radar sangat penting untuk transportasi laut dan udara, perlu dilakukan pengembangan kemampuan dalam negeri Indonesia sendiri untuk penyediaan radar secara mandiri. Dengan keterbatasan jumlah radar dan banyaknya wilayah perairan yang harus dilakukan pengawasan maka diperlukan sistem radar coastal yang bersifat portable.

Portable coastal radar mempunyai keunggulan dalam bentuk kemudahan untuk melakukan pengamatan/monitoring wilayah perairan/pantai dengan berpindah-pindah lokasi sesuai dengan data pengamatan yang ingin diperoleh. Apabila ditempatkan pada posisi yang tinggi terhadap permukaan air laut, maka 
jangkauan wilayah pengamatan akan luas/jauh sedangkan apabila posisinya hanya beberapa meter dari permukaan air laut maka wilayah pengamatan hanya sedikit areanya.

Portable coastal radar yang akan dibuat menggunakan teknologi FM-CW (frequency modulated continuous wave). Gambar 1 memperlihatkan rancangan portable coastal radar yang dapat bersifat stand alone (berdiri sendiri/tidak tergantung pada kendaraan), di mana ada satu kontainer yang berisikan perangkat sistem radar termasuk semua perangkat elektronika, radio frequency, komputer + display, power supply, dan perangkat untuk menaik-turunkan radar. Di belakang kontainer ini terdapat satu sistem generator (genset) untuk memberikan power supply listrik. Kontainer dan genset ini akan ditarik menggunakan kendaraan seperti truk.

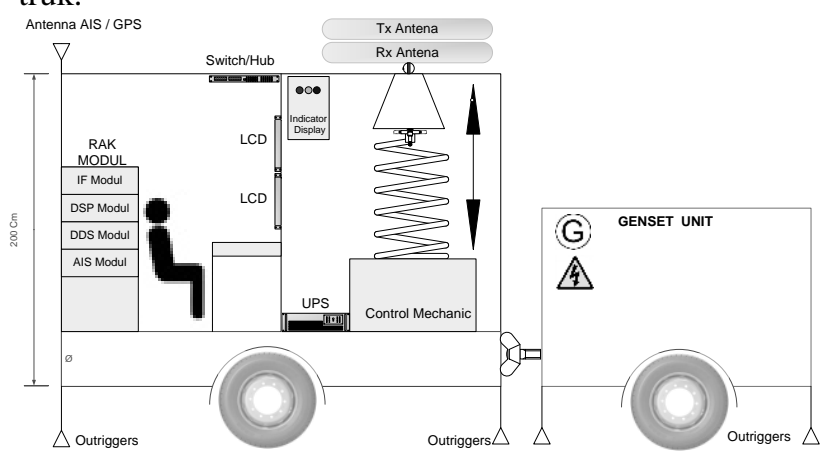

Gambar1. Rancangan Portable Coastal Radar.

Salah satu bagian dari sistem radar adalah antena seperti terlihat pada Gambar 1. Jenis antena yang bisa digunakan untuk sistem coastal radar antara lain antena reflektor dan antena mikrostrip. Antena reflektor mempunyai gain yang besar [3] dan beamwidth yang sempit, tapi untuk frekuensi rendah mempunyai dimensi yang cukup lebar sehingga tidak cocok digunakan pada sistem radar portable. Penggunaan antena mikrostrip dalam sistem radar telah dibahas pada [4], substrat yang digunakan adalah RT 5880 di mana ketersediaan bahan harus diimpor dari luar negeri dan harganya relatif mahal.

Pada penelitian ini akan dibahas tentang desain dan simulasi antena Portabel Coastal Radar dengan menggunakan substrat yang tersedia di dalam negeri sehingga mudah dalam fabrikasi. Radar ini menggunakan frekuensi $S$-band dengan frekuensi kerja 3 $\mathrm{GHz}$. Jenis antena yang digunakan yaitu mikrostrip dengan menambahkan array secara horisontal untuk mempersempit beamwidth dan meningkatkan gain.

\section{TEORI DASAR}

Dalam sistem komunikasi tanpa kabel salah satu komponen yang memegang peranan penting adalah antena. Antena merupakan sebuah perangkat yang digunakan untuk memancarkan dan atau menerima gelombang elektromagnetik. Dapat dikatakan juga bahwa antena adalah transformator antara gelombang terbimbing dengan gelombang bebas [5]. Gelombang elektromagnetik yang dibangkitkan pada sistem pemancar akan dilewatkan dalam suatu saluran transmisi, gelombang elektromagnetik yang masih berada dalam saluran transmisi bisa disebut sebagai gelombang terbimbing, setelah melewati saluran transmisi maka gelombang elektromagnetik akan dipancarkan ke udara bebas, sehingga gelombang elektromagnetik menjadi gelombang bebas. Pada sistem penerima gelombang bebas akan ditangkap antena yang kemudian akan berubah menjadi gelombang terbimbing setelah dilewatkan dalam saluran transmisi, kemudian gelombang elektromagnetik tersebut akan diteruskan ke bagian penerima.

Sedangkan menurut definisi yang terdapat pada The IEEE Standard Definitions of Terms for Antenas, yaitu definisi antena adalah suatu alat yang digunakan untuk meradiasikan atau menerima gelombang radio [6]. Dari sini terlihat bahwa suatu struktur dikatakan antena adalah ketika struktur tersebut dapat berfungsi sebagai penerima maupun, meradiasikan gelombang radio.

Antena mikrostrip adalah antena yang saat ini popular karena memiliki keunggulan-keunggulan yang memenuhi permintaan akan antena yang kecil dan ringan sehingga kompatibel dan mudah diintegrasikan untuk aplikasi yang sifatnya mobile communication [7].

Secara fisik antena mikrostrip ini terlihat sangat sederhana karena hanya berupa lempengan PCB pada umumnya. Pada dasarnya antena mikrostrip terdiri dari tiga bagian yaitu patch, substrat, dan ground plane, ini dapat dilihat pada Gambar 2.

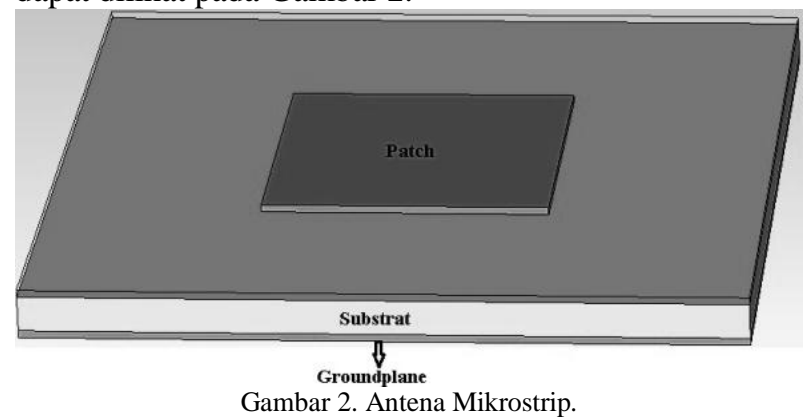

\section{F. Patch Antena Persegi}

Salah satu yang paling mudah dan paling banyak digunakan dalam perancangan patch antena mikrostrip adalah antena patch rektangular.

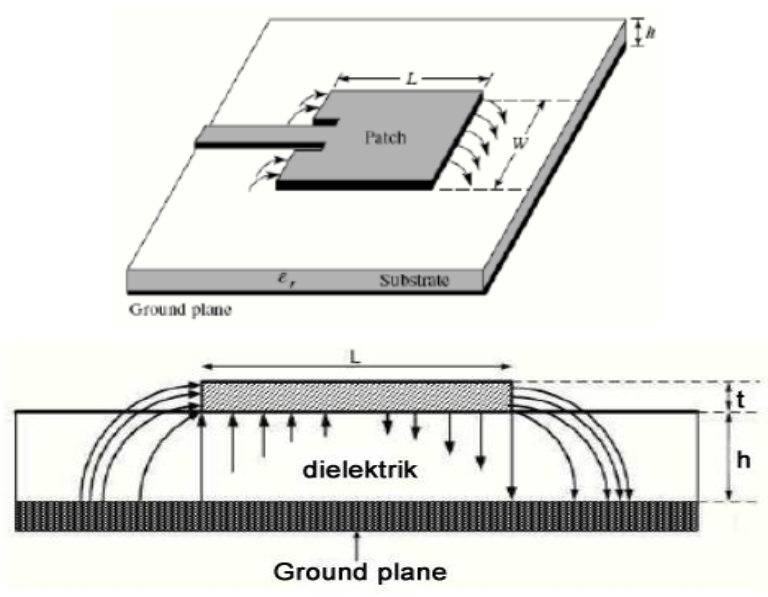

Gambar 3. Distribusi Medan Listrik pada Antena Mikrostrip [8].

Pada antena mikrostrip, panjang patch peradiasi $L$ biasanya dibuat mendekati $\lambda / 2$ ( $\lambda$ di sini adalah wavelength pada substrat) agar rongga antara patch dan ground beresonansi [8] seperti Gambar 3. 
Perancangan antena biasanya menggunakan persamaan di bawah ini untuk menentukan lebar patch $(W)$ optimum [4]:

$W=\frac{c}{2 f r} \sqrt{\frac{2}{\varepsilon_{r}+1}}$

$\varepsilon_{\mathrm{r}}$ merupakan konstanta dielektrik/relative permittivity dari substrat dan c adalah kecepatan cahaya dalam ruang bebas sebesar $3.10^{8} \mathrm{~m} / \mathrm{s}$. Dengan memperhitungkan pengaruh medan limpahan pada sisi yang meradiasi, panjang fisik $(L)$ antena dapat ditentukan dengan cara:

$L=\frac{c}{2 f r \sqrt{\varepsilon_{e f f}}}-2 \Delta L$

dimana $\varepsilon_{\text {eff }}$ adalah konstanta dielektrik efektif, yakni:

$\varepsilon_{\text {eff }}=\frac{\varepsilon r+1}{2}+\frac{\varepsilon r-1}{2} \sqrt{\frac{1}{1+12 \frac{h}{W}}}$

$\Delta L$ adalah besarnya medan limpahan gelombang elektromagnet dari patch, yakni:

$\frac{\Delta L}{h}=0.412 \frac{(\varepsilon e f f+0.3)\left(\frac{W}{h}+0.264\right)}{(\varepsilon e f f+0.258)\left(\frac{W}{h}+0.8\right)}$

$\Delta L=\left[0.412 \frac{(\varepsilon e f f+0.3)\left(\frac{W}{h}+0.264\right)}{(\varepsilon e f f+0.258)\left(\frac{W}{h}+0.8\right)}\right] h$

di mana:

$\mathrm{h}=$ tebal substrat $(\mathrm{mm})$,

$\mathrm{W}=$ lebar patch $(\mathrm{mm})$

\section{G. Antena Array}

Antena array atau sering disebut sebagai phased array adalah susunan dari 2 antena atau lebih. Sinyal dari antena tersebut digabung atau diproses untuk meningkatkan performansi yang diperoleh dari satu antena. Tujuan membuat antena array antara lain untuk meningkatkan gain antena, meningkatkan directivity antena, mengarahkan daya pancar menuju sektor sudut yang diinginkan, menentukan arah kedatangan sinyal, dan memaksimalkan SNR (Signal to Interference Plus Noise Ratio) [9].

Jumlah elemen, pengaturan geometris, amplitudo relatif dan fase relative dari antena yang akan di-array bergantung pada pola sudut yang harus dicapai. Jika antena array telah dirancang untuk fokus ke arah tertentu, maka akan mudah untuk mengarahkan ke beberapa arah lain dengan mengubah fase relative dari elemen array, proses ini disebut steering atau scanning [10].

Gambar 4 menunjukkan beberapa contoh array satu dan dua dimensi yang terdiri dari antena linear yang identik.

Jika sebuah elemen antena linier dipasang searah sumbu z maka akan menghasilkan pola omni directional pada sudut azimut $\varphi$. Dengan mereplikasi elemen antena sepanjang sumbu $\mathrm{x}$ atau sumbu $\mathrm{y}$ maka tidak akan diperoleh sudut azimut $\varphi$ yang simetri. Ketika elemen antena direplikasi sepanjang sumbu $\mathrm{z}$, maka omni directionality yang sehubungan dengan sudut azimut $\varphi$ dapat dipertahankan. Jika kita bisa menentukan jumlah elemen array $\left(a_{n}\right)$ dengan tepat, maka kita dapat memperoleh nilai gain dan beamwidth yang diinginkan.

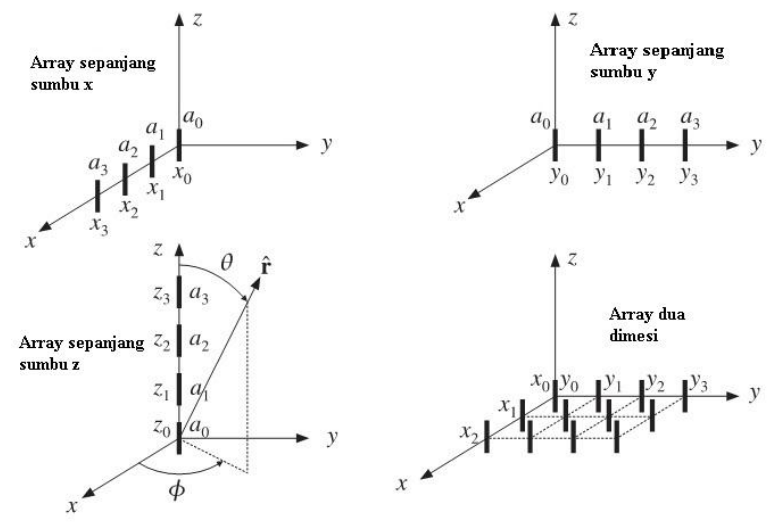

Gambar 4. Konfigurasi Array [10].

\section{PERANCANGAN DAN SIMULASI}

Spesifikasi yang diinginkan dalam perancangan antena Portabel Coastal Radar adalah sebagai berikut :

$\begin{array}{lll}\text { - } & \text { Frekuensi kerja } & : \mathrm{S} \text { Band } \\ \text { - } & \text { Frekuensi tengah } & : 3 \mathrm{GHz} \\ \text { - } & \text { VSWR } & :<1,5 \\ \text { - } & \text { Bandwidth } & : 60 \mathrm{MHz} \\ \text { - } & \text { Beamwidth horisontal } & :<1^{\circ} \\ \text { - } & \text { Impedansi terminal } & : 50 \Omega\end{array}$

Bahan dielektrik yang digunakan sebagai substrat pada antena adalah epoxy FR4. Karakteristik dasar epoxy FR4 sebagai bahan dielektrik yang digunakan untuk realisasi antena ini adalah sebagai berikut :

- Permitivitas relatif $\varepsilon_{r} \quad: 4,3$

- Loss tangent : :0,035

- Ketebalan dielektrik $\quad: 3,2 \mathrm{~mm}$

- Temperatur kerja : $-50 \mathrm{~s} / \mathrm{d} 125^{\circ} \mathrm{C}$

Salah satu kekurangan antena mikrostrip adalah bandwidth yang sempit. Oleh karena itu pada penelitian ini kami menggunakan ketebalan dielektrik $3,2 \mathrm{~mm}$ dengan tujuan memperlebar bandwidth antena agar sesuai dengan spesifikasi yang diinginkan.

Geometri antena array yang didesain dapat dilihat pada Gambar 5.

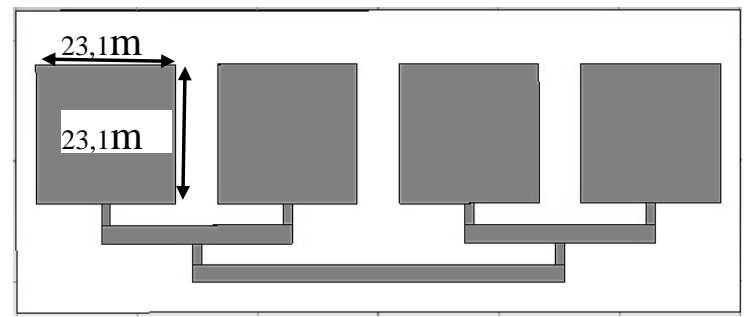

(a)

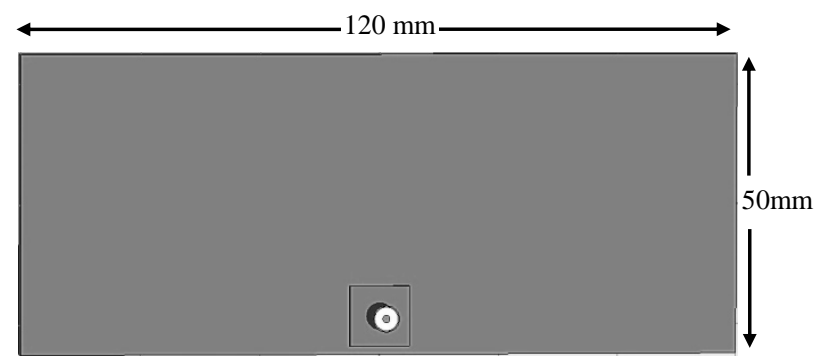

(b)

Gambar 5. (a) Geometri Antena Tampak Depan, (b) Geometri Antena Tampak Belakang. 
Pada Gambar 5 dapat dilihat antena terdiri dari empat buah patch yang di-array secara horisontal, bentuk ini dipilih karena sinyal akan diterima oleh masing-masing patch secara bersamaan karena masingmasing patch mempunyai jarak yang sama dengan titik pencatuan. Pada tampak belakang terlihat antena dicatu dengan menggunakan konektor SMA dengan groundplane selebar substrat. Panjang 1 modul antena adalah $120 \mathrm{~mm}$.

\section{A. Hasil Simulasi 1 Modul Antena}

Antena disimulasi dengan menggunakan software 3D yang bekerja pada domain frekuensi untuk melihat performansi antena yang didesain.

Hasil simulasi parameter $\mathrm{s}_{11}$ dan VSWR antena ditunjukkan pada Gambar 6 dan 7.

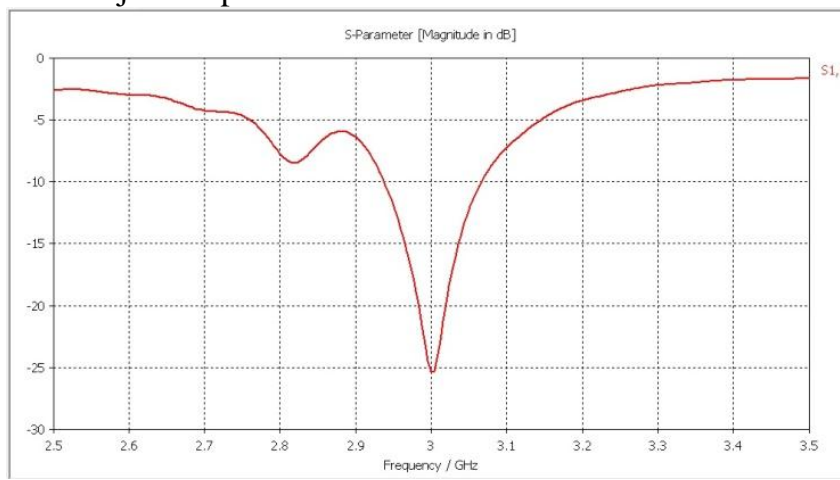

Gambar 6. Hasil Simulasi $\mathrm{S}_{11}$ Antena.

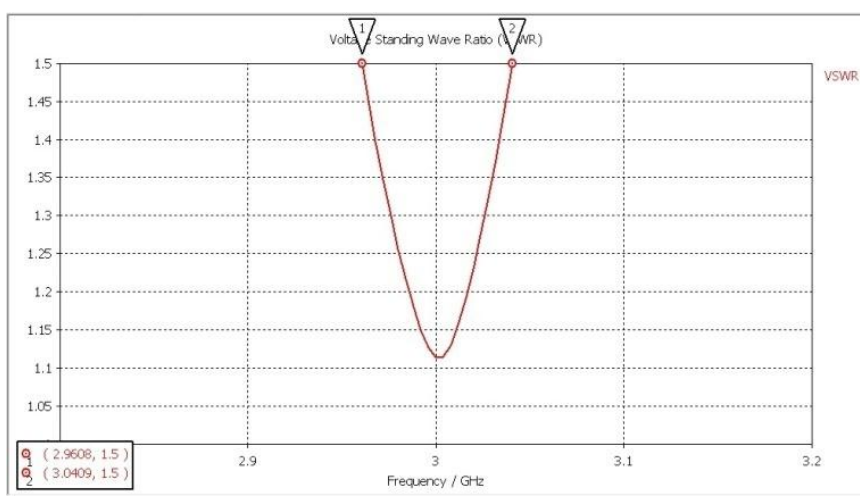

Gambar 7. Hasil Simulasi VSWR Antena.

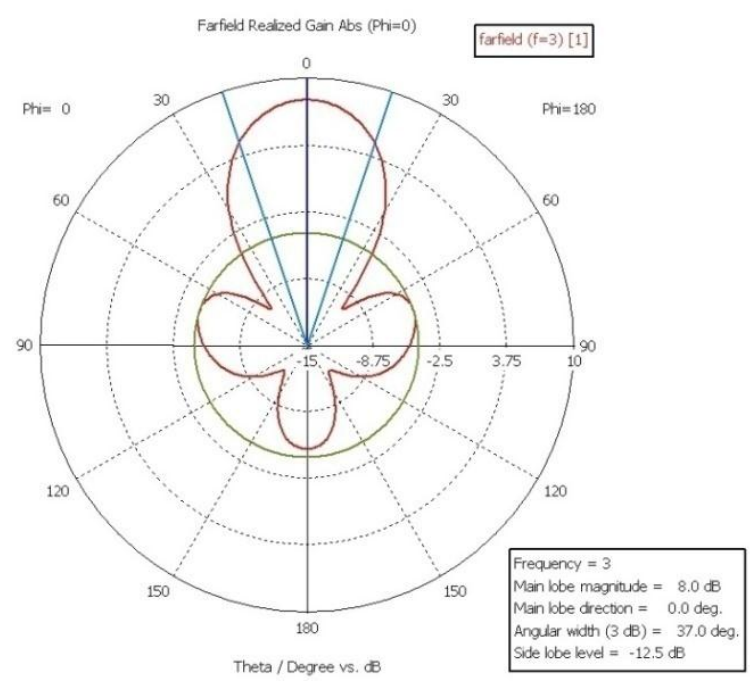

(a)
Dari Gambar 6 dapat disimpulkan antena yang didesain bekerja pada frekuensi yang diinginkan, hal ini terlihat dari nilai return loss terbaik sebesar $-25 \mathrm{~dB}$ diperoleh pada frekuensi $3 \mathrm{GHz}$. Nilai VSWR $\leq 1,5$ diperoleh pada rentang frekuensi 2,9608 sampai dengan 3,0409, sehingga bandwidth antena hasil simulasi sebesar 80,1 MHz.

Pola radiasi antena hasil simulasi dapat dilihat pada Gambar 8. Beamwidth horisontal antena hasil simulasi dapat dilihat pada Gambar 8 (a) yaitu sebesar $37^{\circ}$, sedangkan beamwidth vertikal antena seperti terlihat pada Gambar 8 (b) sebesar 92,1 ${ }^{\circ}$. Beamwidth horisontal antena masih belum sesuai dengan spesifikasi yang diinginkan, sehingga perlu ditambahkan array secara horisontal.

Gain antena hasil simulasi diperoleh sebesar 8,049 dB seperti ditunjukkan pada Gambar 9.

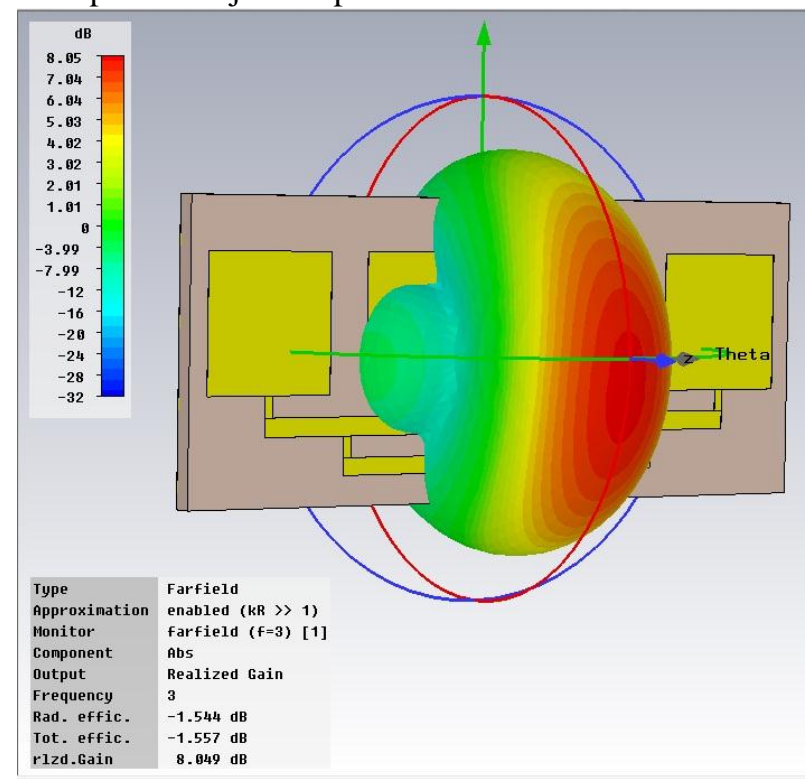

Gambar 9. Hasil Simulasi Gain Antena

\section{B. Hasil Simulasi Antena Array Horisontal}

Untuk memperkecil beamwidth horisontal maka modul antena yang telah disimulasi di-array ke arah horisontal. Geometri antena yang telah di-array ditunjukkan pada Gambar 10.

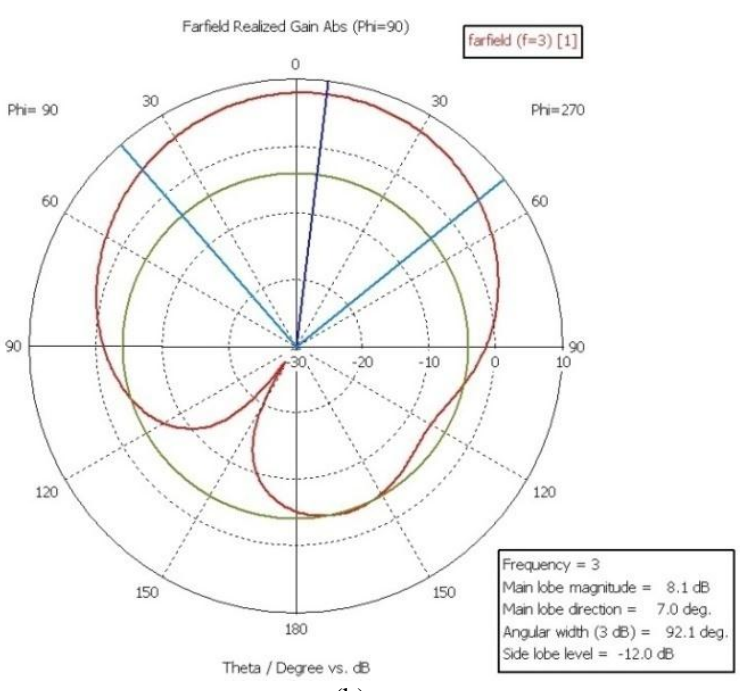

(b)

Gambar 8. Hasil Simulasi Pola Radiasi Antena, (a) Beamwidth Horisontal, (b) Beamwidth Vertikal 


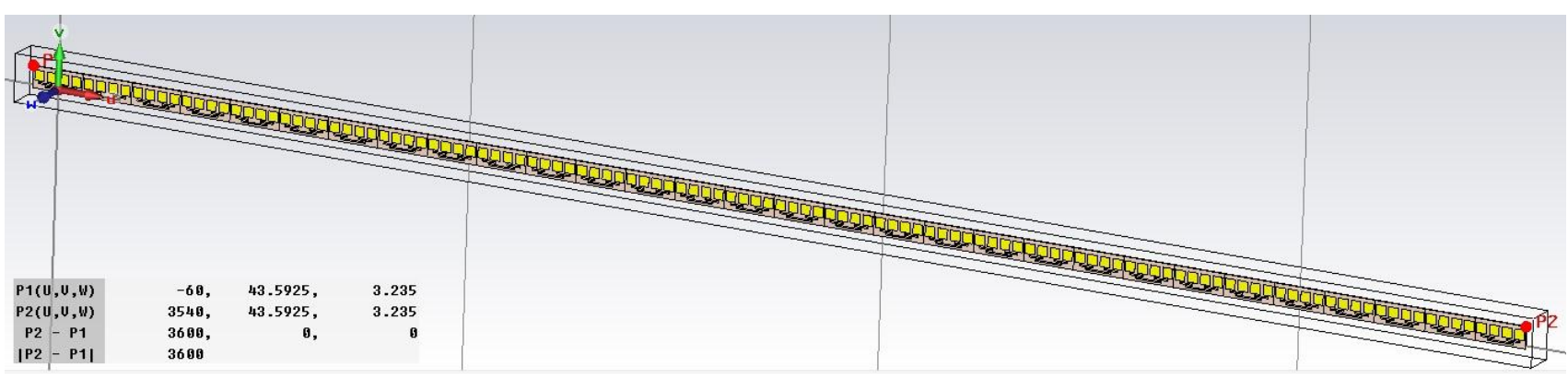

Gambar 10. Geometri Antena Array.

Jumlah antena yang di-array secara horisontal adalah 30 buah modul antena, panjang keseluruhan antena adalah $3600 \mathrm{~mm}$. Hasil simulasi beamwidth antena array dapat dilihat pada Gambar 11.

Farfield (Array) Realized Gain Abs (Theta $=90$ )

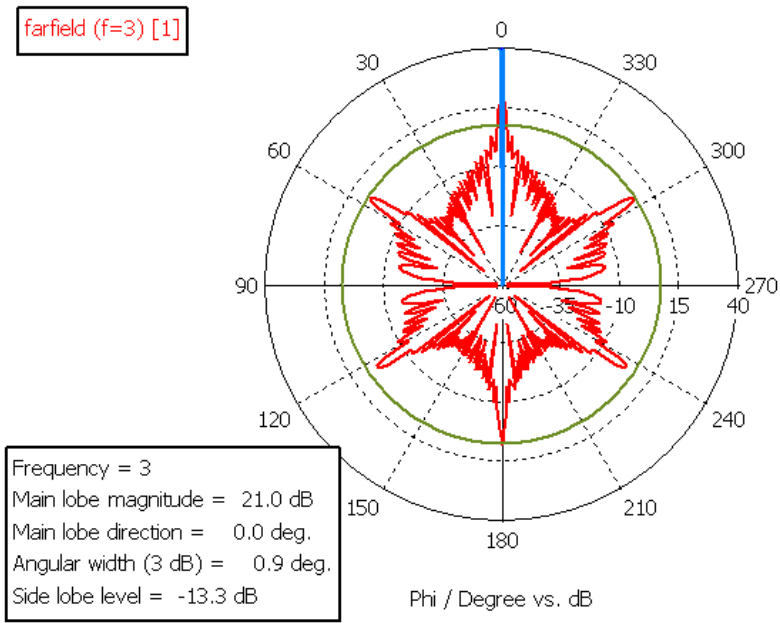

Gambar 11. Beamwidth Horisontal Antena Array.

Terlihat pada Gambar 11 dengan menyusun antena secara horisontal dapat menurunkan beamwidth antena. Beamwidth horisontal antena array hasil simulasi telah memenuhi spesifikasi yang ditentukan yaitu sebesar $0,9^{\circ}$.

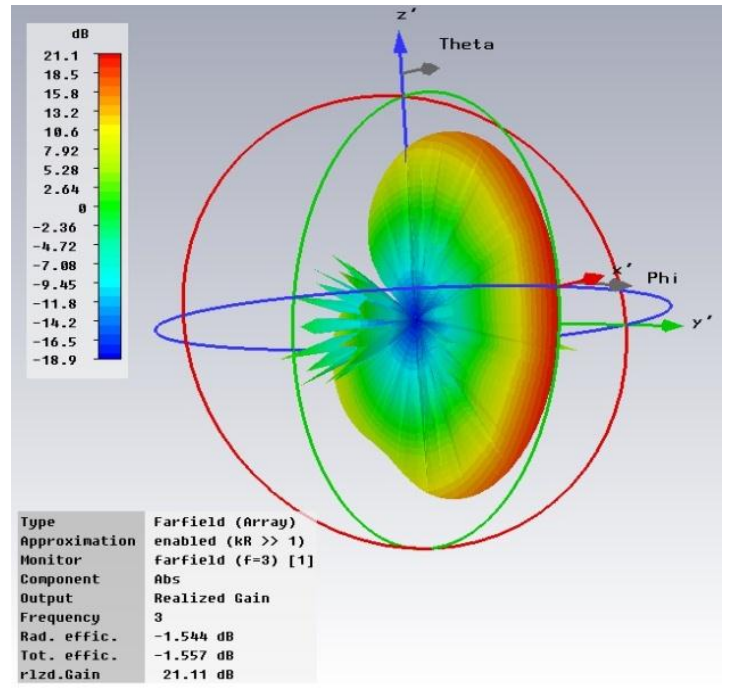

Gambar 12. Hasil Simulasi Gain Antena Array
Dengan bertambahnya jumlah antena yang di-array maka gain antena juga akan meningkat. Antena array dengan jumlah 30 modul antena patch menghasilkan gain sebesar 21,11 dB seperti ditunjukkan pada Gambar 12.

\section{KESIMPULAN}

Antena portable coastal radar yang telah didesain dan disimulasi dapat bekerja pada frekuensi $3 \mathrm{GHz}$ dan menunjukkan performansi kerja yang sesuai dengan spesifikasi yang diinginkan. Dengan menambahkan elemen antena yang di-array secara horisontal terbukti dapat mengurangi beamwidth horisontal dan meningkatkan gain antena. Bandwith antena juga dapat ditingkatkan dengan menambah ketebalan substrat.

Fabrikasi dan pengukuran antena akan dilakukan pada penelitian selanjutnya untuk membandingkan hasil simulasi antena yang didesain.

\section{Daftar Pustaka}

[1] (2013) Radar sebagai mata pengawas wilayah NKRI [Online]. Available: $\quad$ http://www.radar-nasional.org/home/51-radarsebagai-mata-pengawas-wilayah-nkri

[2] Y. Ekawati. (2013), Teknologi radar, dengan radar amati pantai, [Online]. Available: http://www.informatika.lipi.go.id/ipt/index.php?option=com_co ntent \&view=article \&id=195\%3Ateknologi-radar-dengan-radaramati-pesisir\&catid=1\%3Alatest-news\&Itemid=59\&lang=in

[3] M. Alaydrus. (2013), Antena reflector. [Online], Available: http://kk.mercubuana.ac.id/files/14056-8-305986707439.pdf

[4] P. Daud, Y. N. Wijayanto, Sulistyaningsih, dan S. Hardiati, "Antena mikrostrip patch array untuk aplikasi sistem radar maritime", dalam Prosiding Pemaparan Hasil Litbang Ilmu Pengetahuan teknik IV, Bandung 2008, hal B 17-B 21.

[5] H Judawisastra, Antena dan Propagasi Gelombang, Catatan Kuliah, Penerbit ITB, 2010.

[6] The IEEE Standard Definitions of Terms for Antennas, IEEE Std. 145, 1983.

[7] S. Rahmadita, "Perancangan dan Realisasi Antena Mikrostrip Patch Persegi Dengan Substrat Alumina pada Frekuensi 3,3 -3,4 GHz Untuk Aplikasi Wimax", Tugas akhir, Institut Teknologi Telkom, Bandung, 2010.

[8] C. A. Balanis, Antenna Theory Analysis and Design, New Jersey: John Wiley \& Sons, Inc, 2005

[9] (2013) Antenna arrays (Phased arrays). [Online]. Available: http://www.antenna-theory.com/arrays/main.php

[10] (2013) Waveguides. [Online]. http://www.ece.rutgers.edu/ orfanidi/ewa/ch19.pdf
Available: 